\title{
ANALISIS KEPUASAN PENGUNJUNG TERHADAP SARANA TRANSPORTASI PULAU KETAWAI KABUPATEN BANGKA TENGAH
}

\author{
Visitor Satisfaction Analysis Of Transport Facilities Ketawai Island Central Bangka Regency
}

\author{
Melia Umayya ${ }^{1)}$, Wahyu Adi ${ }^{2)}$, Kurniawan²) \\ 1) Mahasiswa, Program Studi Manajemen Sumberdaya Perairain \\ ${ }^{2)}$ Staff Pengajar, Program Studi Manajemen Sumberdaya Perairan \\ Email koresponden : meliawardana21@gmail.com
}

\begin{abstract}
Abstrak
Pulau Ketawai adalah salah satu pulau kecil yang terdapat di Desa Kurau, Kabupaten Bangka Tengah yang memiliki potensi perikanan dan pariwisata yang cukup tinggi. Pengembangan pariwisata bahari suatu daerah tidak terlepas dari ketersediaan sarana transportasi untuk mencapai obyek wisata. Permasalahan yang timbul pada transportasi menuju Pulau Ketawai adalah belum ada kajian kepuasan wisatawan terhadap transportasi pariwisata. Tujuan penelitian ini adalah untuk menganalisis kepuasan pengunjung terhadap sarana transportasi Pulau Ketawai Kabupaten Bangka Tengah. Penelitian ini dilakukan pada bulan April 2016. Lokasi Penelitian dilaksanakan di Pulau Ketawai Kabupaten Bangka Tengah. Penelitian ini menggunakan variabel independen meliputi Bukti Fisik $\left(\mathrm{X}_{1}\right)$, Kehandalan $\left(\mathrm{X}_{2}\right)$, Daya Tanggap $\left(\mathrm{X}_{3}\right)$, Jaminan $\left(\mathrm{X}_{4}\right)$ dan Empati $\left(\mathrm{X}_{5}\right)$ dan variabel dependen yaitu Kepuasan Pengunjung $(\mathrm{Y})$. Analisis data yang digunakan adalah analisis regresi linear berganda. Hasil yang didapat pada analisis regresi linear berganda menghasilkan persamaan regresi tingkat kepuasan pengunjung $Y^{\prime}=16,661 \mathrm{a}+0,591 \mathrm{X}_{1}+0,322 \mathrm{X}_{2}-0,205 \mathrm{X}_{3}-0,693$ $\mathrm{X}_{4}-0,072 \mathrm{X}_{5}$. Persamaan regresi menunjukan bahwa variabel $X_{1}$ dan $X_{2}$ berpengaruh positif terhadap kepuasan pengunjung sehingga perlu ditingkatkan sedangkan variabel $X_{3}, X_{4}$ dan $X_{5}$ berpengaruh negatif terhadap kepuasan pengunjung sehingga perlu diturunkan untuk meningkatkan kepuasan pengunjung.
\end{abstract}

Kata kunci : Pulau Ketawai, Pariwisata, Transportasi, Kepuasan, Pengunjung

\section{PENDAHULUAN}

Wilayah Kabupaten Bangka Tengah terletak di Pulau Bangka dengan luas lebih kurang 2.155,77 $\mathrm{Km}^{2}$ atau 215.577 Ha. Dikelilingi oleh 12 pulau-pulau kecil dengan panjang garis pantai $\pm 195 \mathrm{~km}$ (KKP, 2012). Pulau-pulau kecil di wilayah Kabupaten Bangka Tengah memiliki potensi perikanan dan pariwisata yang cukup tinggi. Namun selama ini belum dikembangkan secara maksimal. Mulai tahun 2011, pemerintah Kabupaten Bangka Tengah mulai mengembangkan pulau-pulau kecil untuk perikanan dan pariwisata. Salah satu target pengembangan pulau-pulau kecil yakni Pulau Ketawai dengan luas sekitar 29 Ha sebagai kawasan wisata.

Pulau Ketawai adalah salah satu pulau kecil yang terdapat di Desa Kurau, Kabupaten Bangka Tengah yang memiliki potensi perikanan dan pariwisata yang cukup tinggi. Pulau Ketawai terletak pada posisi geogafis 02 $16^{\prime} 04^{\prime \prime}$ 'LS dan 106'19'31', BT (KKP, 2012). Pulau Ketawai dijadikan sebagai objek wisata pantai karena memiliki daya tarik yang dapat menarik minat wisata untuk berkunjung ke pulau ini. Wisatawan yang datang ke Pulau Ketawai merupakan wisatawan lokal (domestic) maupun wisatawan asing (foreign tourist). Perjalanan menuju ke Pulau Ketawai dapat ditempuh melalui jalur laut dari dermaga Desa Kurau dengan moda transportasi kapal menuju pulau tersebut dengan waktu tempuh \pm 1 jam. Transportasi ke Pulau Ketawai biasanya memanfaatkan kapal nelayan sebagai pekerjaan sampingan para nelayan disaat tidak melaut.

Pengembangan pariwisata bahari suatu daerah tidak terlepas dari ketersediaan sarana transportasi untuk mencapai obyek wisata tersebut. Sarana transportasi berhubungan dengan tingkat kemudahan pencapaian lokasi, baik melalui darat maupun laut. Transportasi merupakan unsur yang sangat berpengaruh dalam suatu pengembangan pariwisata. Transportasi pariwisata berfungsi sebagai pendorong, penunjang dan penggerak pertumbuhan pariwisata. Jadi jika sektor transportasi tidak digarap dengan baik maka dapat dipastikan pengembangannya tidak dapat dinikmati secara optimal dan mempengaruhi jumlah kunjungan serta tingkat kepuasan pengunjung.

Permasalahan yang timbul pada transportasi menuju Pulau Ketawai adalah belum adanya kajian kepuasan wisatawan terhadap transportasi pariwisata. Kemudian fasilitas transportasi laut yang dapat menunjang keamanan dan kenyamanan pengunjung, kemudahan pencapaian yang dapat mempersingkat waktu tempuh, kesesuaian tarif dan kualitas pelayanan transportasi yang masih terbilang buruk. Hal tersebut akan memberikan pengaruh terhadap rasa keamanan dan kenyamanan perjalanan para pengunjung dalam menentukan tingkat kepuasan pengunjung. Penelitian ini diharapkan dapat memberi informasi tentang kepuasan pengunjung terhadap sarana transportasi Pulau Ketawai Kabupaten Bangka Tengah. Kondisi ini diperlukan agar kepuasan wisatawan dapat terjaga dan meningkatkan pendapatan daerah setempat khususnya Desa Kurau Kabupaten Bangka Tengah, serta dapat menjadikan Pulau Ketawai sebagai destinasi pariwisata yang berkelanjutan.

Penelitian ini bertujuan untuk menganalisis kepuasan pengunjung terhadap sarana transportasi Pulau Ketawai Kabupaten Bangka Tengah. Penelitian ini diharapkan dapat bermanfaat sebagai informasi bagi masyarakat/ pemerintah Desa Kurau tentang pentingnya fasilitas transportasi pariwisata dalam menentukan 
kepuasan wisatawan serta informasi bagi instansi terkait untuk memperhatikan dan memperbaiki sistem pengembangan transportasi pariwisata Pulau Ketawai.

\section{METODE PENELITIAN}

Data yang dibutuhkan dalam penelitian ini adalah data primer diperoleh melalui pengumpulan data secara langsung. Data primer yang digunakan berupa kuisioner yang meliputi karakteristik responden, pola kunjungan responden, variabel independen dan variabel dependen yang ditujukan kepada pengunjung Pulau Ketawai.

Pemilihan responden dilakukan dengan metode purposive sampling yaitu pengambilan anggota sampel berdasarkan pertimbangan peneliti yang dianggap mewakili populasi yang ada (Sugiyono, 2009). Pertimbangan peneliti dalam hal ini adalah :

1. Responden merupakan pengunjung yang sedang melakukan perjalanan ke Pulau Ketawai saat penelitian berlangsung, dimana pengunjung merupakan objek utama penelitian (Kusmayadi, 2004).

2. Pengunjung yang dijadikan responden berusia $>17$ 50 tahun yang termasuk dalam kelompok pemuda dan kelompok dewasa dari rata-rata jumlah keberangkatan disaat penelitian berlangsung (Ismayanti, 2010).

3. Pengunjung yang dijadikan responden dipilih secara bebas tanpa batasan wilayah/ tanpa membedakan asal wisatawan (Kusmayadi, 2004). Pengambilan Sampel berdasarkan rumus Fauzi (2001) yaitu sebagai berikut:

Keterangan:

$$
n=\frac{N \cdot Z^{2} \cdot 0,25}{\left[\mathrm{~d}^{2}(N-1)\right]+\left[Z^{2} \cdot 0,25\right]}
$$

$\begin{array}{ll}\mathrm{n} & \text { : Jumlah sampel } \\ \mathrm{N} & \text { : Jumlah populasi } \\ 1 & \text { : Konstanta } \\ 0,25 & \text { : Konstanta } \\ \mathrm{D} & \text { : Persen kelonggaran ketidaktelitian } \\ \text { (nilai e: } 10 \%) & \\ \mathrm{Z} & \text { : Tingkat kebenaran 90\% pada tabel Z }\end{array}$

(nilai Z: 1,29)

Jumlah pengunjung 1 tahun terakhir adalah 3.260 orang, maka responden yang diambil adalah :

$$
\begin{gathered}
n=\frac{N \cdot Z^{2} \cdot 0,25}{\left[\mathrm{~d}^{2}(N-1)\right]+\left[Z^{2} \cdot 0,25\right]} \\
n=\frac{3260 \cdot 1,29^{2} \cdot 0,25}{\left[0,1^{2}(3260-1)\right]+\left[1,29^{2} \cdot 0,25\right]} \\
n=\frac{3260 \cdot 1,664 \cdot 0,25}{[0,01(3259)]+[1,664 \cdot 0,25]} \\
n=\frac{1356,16}{32,59+0,416} \\
n=\frac{1356,16}{33,006}
\end{gathered}
$$

$$
\begin{gathered}
n=41.088 \\
n=42
\end{gathered}
$$

Jadi, responden yang diambil adalah 42 orang pengunjung.

\section{ANALISIS DATA}

Analisis yang digunakan dalam penelitian ini adalah analisis statistik. Analisis Statistik adalah analisis dengan menggunakan pendekatan atau rumus statistik. Penelitian ini dianalisis berdasarkan uraian hasil jawaban dari kuisioner yang telah disebarkan kepada pengunjung Pulau Ketawai yang telah menggunakan pelayanan jasa transportasi ke Pulau Ketawai dan dinyatakan dalam bentuk tabulasi data.

Penelitian ini menggunakan aplikasi analisis statistik yaitu SPSS 20. Analisis statistik yang digunakan adalah Analisis determinasi $\left(\mathrm{R}^{2}\right)$, Uji koefisien regresi secara bersama-sama (uji- F), Uji regresi secara parsial (uji- t). dan Analisis regresi linier berganda.

\section{Analisis determinasi $\left(R^{2}\right)$}

Analisis determinasi digunakan untuk mengetahui pengaruh variabel independen secara serentak terhadap variabel dependen. Koefisien ini menunjukkan seberapa besar persentase variasi variabel independen yang digunakan mampu menjelaskan variasi variabel dependen. Rumus koefisien determinasi (Priyatno, 2013) :

$$
\mathrm{R}^{2}=\frac{(r y X 1)^{2}+(r y X 2)^{2}+(r y X n)^{2}-2(r y X 1)(r y X 2)(r y X n) \cdot(r x 1 \cdot x 2 \cdot x n)}{1-(r x 1 \cdot x 2 \cdot x n)^{2}}
$$

Keterangan:

$$
\begin{array}{ll}
\mathrm{R}^{2} & =\text { Koefisien Determinasi } \\
\operatorname{ryx}_{1} & =\text { Korelasi sederhana antara } \mathrm{X}_{1} \text { dan Y } \\
\operatorname{ryx}_{2} & =\text { Korelasi sederhana antara } \mathrm{X}_{2} \text { dan Y } \\
\operatorname{ryx}_{\mathrm{n}} & =\text { Korelasi sederhana antara } \mathrm{X}_{\mathrm{n}} \text { dan Y } \\
\operatorname{rx}_{1} \cdot \mathrm{x}_{2} \ldots \mathrm{x}_{\mathrm{n}}=\text { Korelasi sederhana antara } \mathrm{x}_{1}, \mathrm{x}_{2}, \ldots . \mathrm{x}_{\mathrm{n}}
\end{array}
$$

\section{Uji koefisien regresi secara bersama-sama (uji- F)}

Uji koefisien regresi secara bersama-sama (uji- F) digunakan untuk mengetahui apakah variabel independen $\left(\mathrm{X}_{1}, \mathrm{X}_{2}, \mathrm{X}_{3}, \mathrm{X}_{4}, \mathrm{X}_{5}\right)$ secara bersama-sama berpengaruh secara signifikan terhadap varian tabel dependen (Y). F-hitung dapat dicari dengan rumus sebagai berikut (Priyatno, 2013):

$$
\mathrm{F} \text { hitung }=\frac{\mathrm{R}^{2} / \mathrm{k}}{\left(1-\mathrm{R}^{2}\right) /(\mathrm{n}-\mathrm{k}-1)}
$$

Keterangan:

$$
\begin{array}{ll}
\mathrm{R}^{2} & =\text { Koefisien Determinasi } \\
\mathrm{n} & =\text { Jumlah data } \\
\mathrm{k} & =\text { Jumlah variabel independen }
\end{array}
$$

Rumusan Hipotesis :

$\mathrm{H}_{0}$ : Tidak ada pengaruh antara variabel independen secara bersama-sama terhadap variabel dependen $\mathrm{H}_{\mathrm{a}}$ : Ada pengaruh antara variabel independen secara bersama-sama terhadap variabel dependen

Kriteria Pengujian:

$\mathrm{H}_{0}$ diterima bila Fhitung $\leq$ Fkritis

$\mathrm{H}_{0}$ ditolak bila Fhitung $>$ Fkritis 


\section{Uji regresi secara parsial (uji- $t$ )}

Uji regresi secara parsial (uji- t) digunakan untuk mengetahui model regresi variabel independen $\left(X_{1}, X_{2}\right.$, $\mathrm{X}_{3}, \mathrm{X}_{4}, \mathrm{X}_{5}$ ) secara parsial (individu) berpengaruh atau tidak terhadap variabel dependen (Y). Rumus t hitung (Priyatno, 2013):

$$
\text { thitung }=\frac{b i}{S b i}
$$

Keterangan:

bi : Koefisien regresi variabel i

Sbi : Standar error variabel i

Rumusan Hipotesis :

$\mathrm{H}_{0}$ : Variabel independen $\left(\mathrm{X}_{1} / \mathrm{X}_{2} / \mathrm{X}_{3} / \mathrm{X}_{4} / \mathrm{X}_{5}\right)$ secara parsial tidak berpengaruh terhadap kepuasan pengunjung

$\mathrm{H}_{\mathrm{a}}$ : Variabel independen $\left(\mathrm{X}_{1} / \mathrm{X}_{2} / \mathrm{X}_{3} / \mathrm{X}_{4} / \mathrm{X}_{5}\right)$ secara parsial berpengaruh terhadap kepuasan pengunjung

Kriteria Pengujian:

$\mathrm{H}_{0}$ diterima bila $\mathrm{t}$ hitung $\leq \mathrm{t}$ kritits

$\mathrm{H}_{0}$ ditolak bila $\mathrm{t}$ hitung $>\mathrm{t}$ kritis

\section{Analisis Regresi Linier Berganda}

Analisis regresi linier berganda adalah hubungan secara linier antara dua atau lebih variabel independen $\left(\mathrm{X}_{1}, \mathrm{X}_{2}, \ldots . \mathrm{X}_{\mathrm{n}}\right)$ dengan Variabel dependen $(\mathrm{Y})$. Rumus persamaan regresi linier berganda adalah sebagai berikut (Priyatno, 2010):

$$
Y^{\prime}=a+b_{1} X_{1}+b_{2} X_{2}+\ldots .+b_{n} X_{n}
$$

Keterangan:

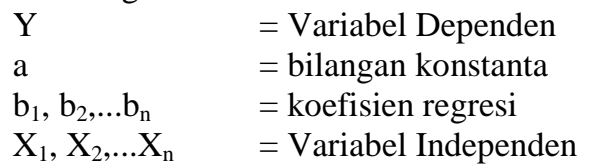

Penelitian ini menggunakan 5 variabel independen $(\mathrm{X})$ untuk melihat pengaruh variabel dependen (Y). Jadi, Rumus persamaan linier bergandanya adalah sebagai berikut (Sugiyono, 2009):

$$
\mathrm{Y}^{\prime}=\mathrm{a}+\mathrm{b} 1 \mathrm{X} 1+\mathrm{b} 2 \mathrm{X} 2+\mathrm{b} 3 \mathrm{X} 3+\mathrm{b} 4 \mathrm{X} 4+\mathrm{b} 5 \mathrm{X} 5
$$

\section{Keterangan :}

$\mathrm{Y}^{\prime} \quad=$ variabel kepuasan pengunjung

a = bilangan konstanta

$\mathrm{b}_{1} \quad=$ nilai peningkatan/penurunan variabel bukti fisik (tangibles)

$\mathrm{b}_{2} \quad=$ nilai peningkatan/penurunan variabel kehandalan (reliability)

$\mathrm{b}_{3} \quad=$ nilai peningkatan/penurunan variabel ketanggapan (responsiveness)

$\mathrm{b}_{4}=$ nilai peningkatan/penurunan variabel jaminan (assurance)

$\mathrm{b}_{5} \quad=$ nilai peningkatan/penurunan variabel empati (emphaty)

$\mathrm{X}_{1}=$ variabel bukti fisik (tangibles)

$\mathrm{X}_{2}=$ variabel kehandalan (reliability)

$\mathrm{X}_{3}=$ variabel ketanggapan (responsiveness)

$\mathrm{X}_{4}=$ variabel jaminan (assurance)

$\mathrm{X}_{5} \quad=$ variabel empati (emphaty)

\section{HASIL DAN PEMBAHASAN}

HASIL

\section{Transportasi Pulau Ketawai}

Pulau Ketawai adalah salah satu pulau kecil yang berada di Desa Kurau Kabupaten Bangka Tengah. Pulau ini banyak menarik wisatawan dan sudah cukup dikenal karena keindahannya baik oleh wisatawan lokal (domestic) maupun wiatawan asing (foreign tourist). Wisatawan yang akan berkunjung ke Pulau Ketawai akan diberangkatkan dari dermaga pelabuhan Desa Kurau. Pulau ini dapat ditempuh melalui jalur laut menggunakan kapal. Transportasi ke Pulau Ketawai merupakan pekerjaan sampingan nelayan disaat para nelayan tidak melakukan aktivitas mencari ikan. Perjalanan menuju Pulau Ketawai dapat ditempuh dengan perkiraan waktu 40-60 menit dengan jarak sekitar 12,477 km. Kapal yang disediakan untuk mengantar pengunjung menuju Pulau Ketawai terbuat dari kayu, memiliki panjang berkisar dari 10-15 $\mathrm{m}$ dan lebar 2,5m dengan kapasitas mesin kapal sebesar 100120 PK atau setara muatan mobil truk, pickup atau box. Satu kapal berisi 20 orang pengunjung dan dikenakan biaya perjalanan mulai dari Rp.800.000 1.000.000/kapal (Wawancara, 2016). Transportasi menuju Pulau Ketawai masih terhitung usaha milik pribadi karena belum ada campur tangan dari berbagai pihak baik pemerintah maupun swasta. Wisatawan yang ingin berkunjung biasanya memesan jasa transportasi melalui via telepon dan tidak ada pecatatan jumlah pengunjung yang diantar setiap keberangkatan ke Pulau Ketawai.

\section{Karakteristik Pengunjung Pulau Ketawai}

Karakteristik pengunjung yang dilihat dalam penelitian ini terdiri dari jenis kelamin, umur, asal, tingkat pendidikan, dan pendapatan.

\section{Jenis Kelamin Pengunjung}

Hasil persentase karakteristik pengunjung Pulau Ketawai berdasarkan jenis kelamin didominasi oleh lakilaki sebesar $62 \%$ dan perempuan 38\% dapat dilihat pada Gambar 1. Hal ini berhubungan dengan perbedaan sifat dimana laki-laki bersifat rasional dan perempuan bersifat emosional.

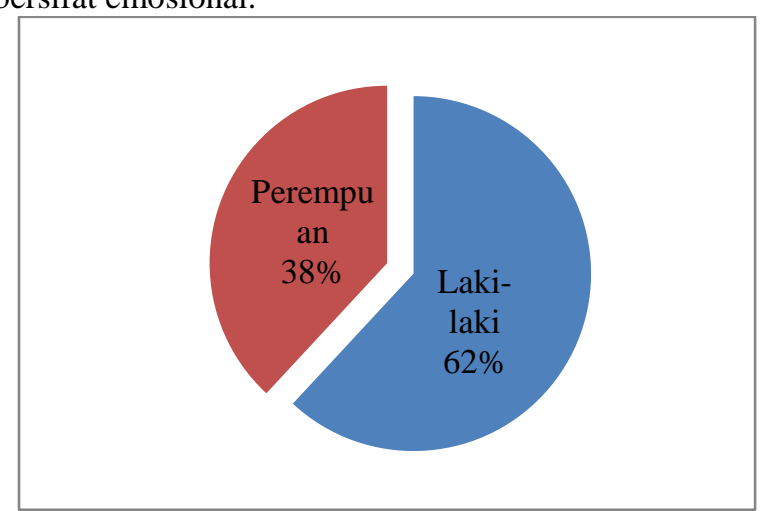

Gambar 1. Persentase Jenis Kelamin Pengunjung Pulau Ketawai 


\section{Umur Pengunjung}

Hasil persentase karakteristik pengunjung Pulau Ketawai berdasarkan umur didominasi oleh kelompok dewasa berumur 24-50 tahun sebesar $60 \%$ dan sisanya kelompok pemuda berumur 17-23 tahun sebesar $40 \%$ dapat dilihat pada Gambar 2. Perbedaan persentase umur tidak berbeda jauh karena pada tingkat umur tersebut pengunjung memiliki kondisi fisik yang baik untuk berwisata.

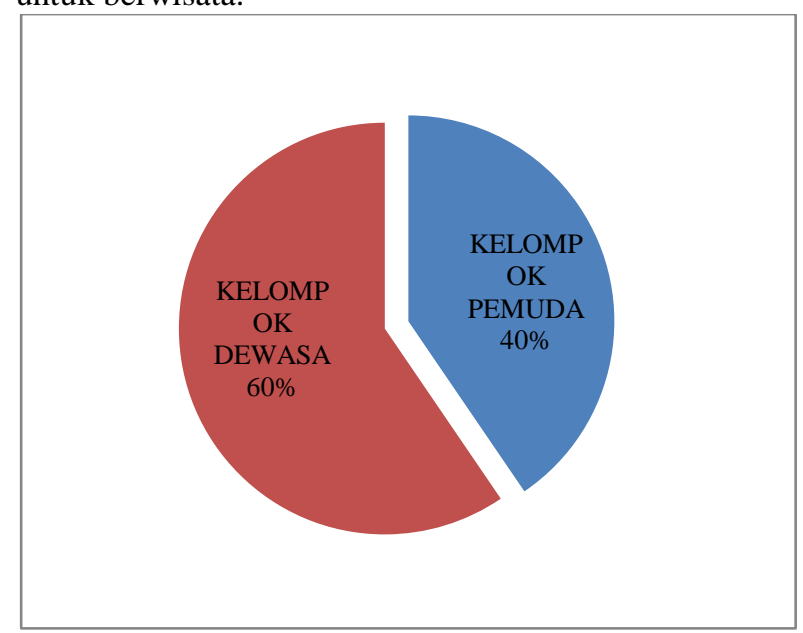

Gambar 2. Persentase Umur Pengunjung Pulau Ketawai

\section{Asal Pengunjung}

Hasil persentase karakteristik pengunjung Pulau Ketawai berdasarkan asal pengunjung dari Pulau Bangka sebesar $88 \%$ dan luar Bangka sebesar $12 \%$ dapat dilihat pada Gambar 3. Pengunjung yang berasal dari Bangka lebih banyak karena lokasi, jarak dan waktu mudah dicapai.

Gambar 3. Persentase Asal Pengunjung Pulau Ketawai

\section{Tingkat Pendidikan Pengunjung}

Hasil persentase karakteristik pengunjung Pulau Ketawai berdasarkan tingkat pendidikan SD 5\%, SMP 5\%, SMA 50\%, D3 19\%, S1 19\%, dan S2 2\% dapat dilihat pada Gambar 4. Latar belakang pendidikan berkaitan dengan preferensi dalam pemilihan kegiatan berwisata sesuai kemapuan sosial baik dari segi pendapatan maupun standar kebutuhan wisata.

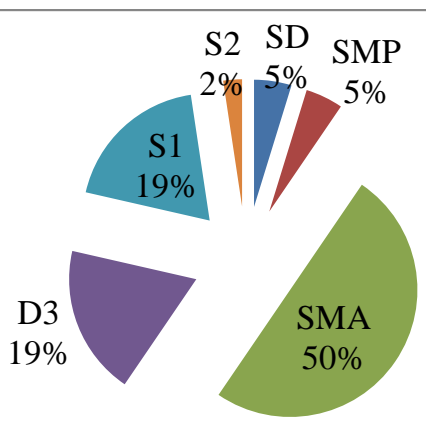

Gambar 4. Persentase Tingkat Pendidikan Pengunjung Pulau Ketawai

\section{Pendapatan Pengunjung}

Hasil persentase karakteristik pengunjung Pulau Ketawai berdasarkan pendapatan paling besar $36 \%$ yaitu Rp.2.000.000-3.000.000 dapat dilihat pada Gambar 5. Pendapatan berkaitan dengan biaya yang akan dianggarkan saat ingin melakukan kegiatan wisata.

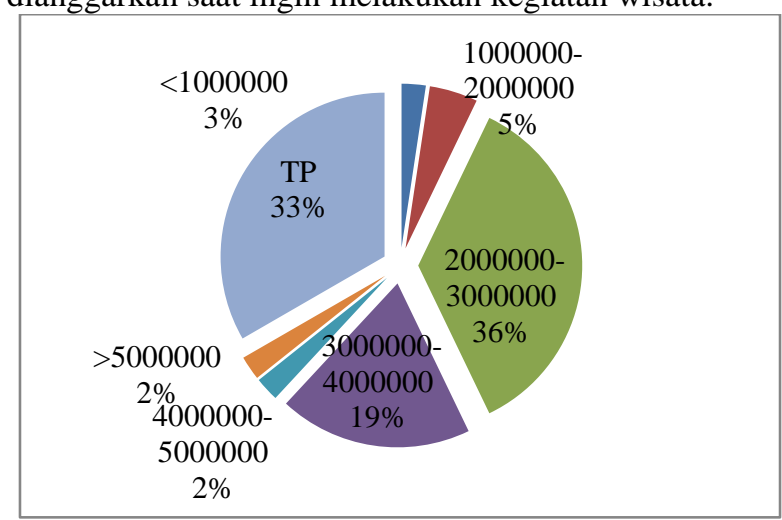

Gambar 5. Persentase Pendapatan Pengunjung Pulau Ketawai

\section{Pola Kunjungan Pengunjung Pulau Ketawai}

Pola kunjungan terdiri dari tujuan kunjungan, jumlah kunjungan, teman perjalanan serta tarif perjalanan. Berikut persentase dari setiap pola pengunjung Pulau ketawai:

\section{Tujuan Kunjungan Pengunjung}

Hasil persentase karakteristik pengunjung Pulau Ketawai berdasarkan tujuan kunjungan $100 \%$ adalah rekreasi dapat dilihat pada Gambar 6.

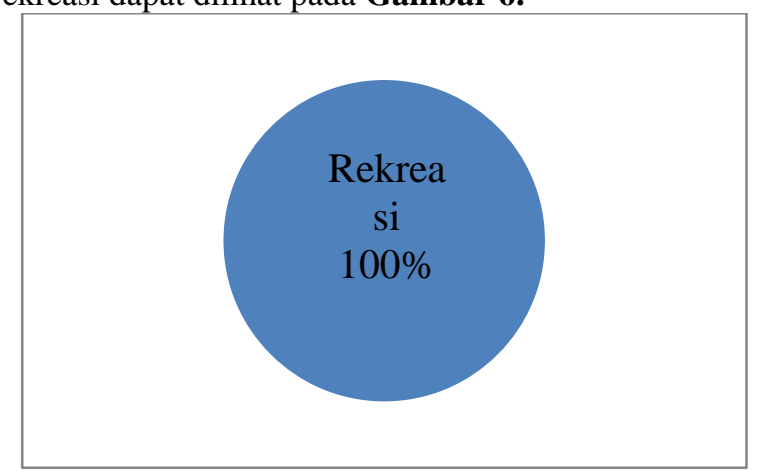

Gambar 6. Tujuan Kunjungan Pengunjung Pulau Ketawai 


\section{Jumlah Kunjungan Pengunjung}

Hasil persentase karakteristik pengunjung Pulau Ketawai berdasarkan jumlah kunjungan paling banyak 1x dengan persentase sebesar $69 \%$, 2x sebesar $22 \%$, 3x sebesar $5 \%$, dan yang berkunjung $4-5 \mathrm{x}$ masing-masing $2 \%$ dapat dilihat pada Gambar 7. Jumlah kunjungan berkaitan dengan keterjangkauan jarak tempuh, waktu perjalanan, dan biaya perjalanan.

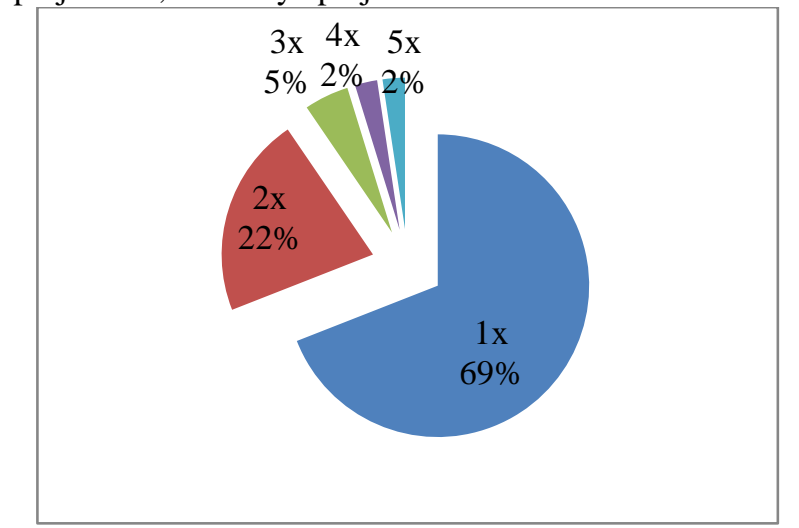

Gambar 7. Jumlah Kunjungan Pengunjung Pulau Ketawai

\section{Teman Perjalanan Pengunjung}

Hasil persentase karakteristik pengunjung Pulau Ketawai berdasarkan teman perjalanan dengan pengunjung yang berwisata bersama rekan kerja sebesar $38 \%$, keluarga $33 \%$, dan teman $29 \%$ dapat dilihat pada Gambar 8. Hal ini berkaitan dengan umur dan pendapatan yang menunjang perjalanan wisata pengunjung itu sendiri.

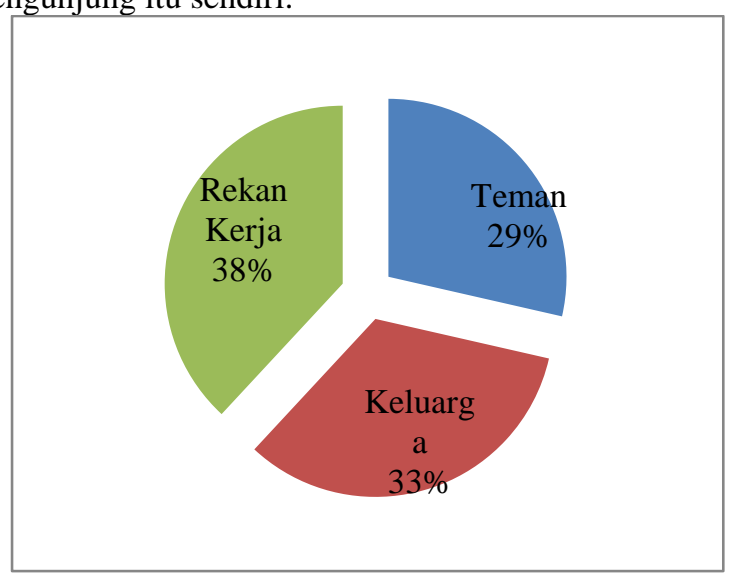

\section{Gambar 8. Teman Perjalanan Pengunjung Pulau Ketawai}

\section{Tarif Kapal Pengunjung Pulau Ketawai}

Hasil persentase karakteristik pengunjung Pulau Ketawai berdasarkan tarif kapal paling besar $>$ Rp.50.000 dengan persentase sebesar 88\% dan tarif terkecil Rp.40.000-50.000 dengan persentase sebesar $12 \%$ dapat dilihat pada Gambar 9. Tarif yang dikeluarkan pengunjung Pulau Ketawai masih tergolong besar melebihi biaya yang telah disesuaikan dengan jumlah pengunjung/kapal.

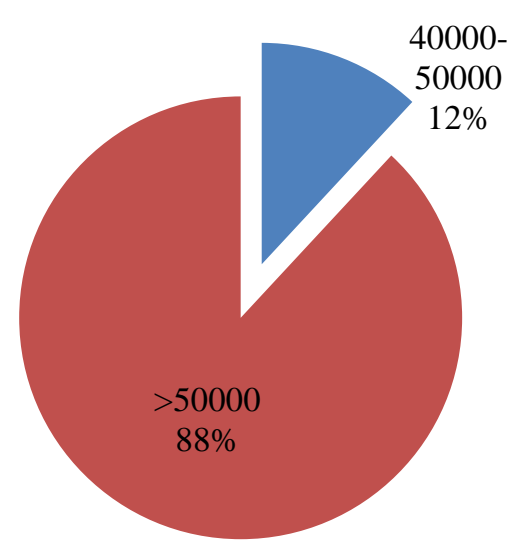

Gambar 9. Tarif Kapal Pengunjung Pulau Ketawai

\section{Analisa Kepuasan Pengunjung Pulau Ketawai}

Analisa kepuasan pengunjung berasal dari uraian hasil jawaban dari kuisioner yang telah dinyatakan dalam bentuk tabulasi data. Tabulasi data kemudian dianalisa menggunakan SPSS 20.

\section{Analisis determinasi $\left(R^{2}\right)$}

Analisa determinasi digunakan untuk mengetahui besaran persentase sumbangan pengaruh variabel independen $\left(\mathrm{X}_{1}, \mathrm{X}_{2}, \mathrm{X}_{3}, \mathrm{X}_{4}, \mathrm{X}_{5}\right)$ secara serentak terhadap variabel dependen (Y). Hasil $\mathrm{R}^{2}$ dapat dilihat pada Tabel 2. Nilai $R^{2}=0,339$ artinya variasi dari variabel independen hanya mampu menjelaskan variasi variabel dependen sebesar 33,9 \% sedangkan sisanya 66,1\% dipengaruhi oleh variabel lain yang tidak dimasukkan kedalam penelitian ini.

Tabel 2. Hasil $\mathrm{R}^{2}$

\begin{tabular}{cccc}
\hline Variabel & $\mathrm{R}$ & $\mathrm{R}^{2}$ & Keterangan \\
\hline $\mathrm{X}_{1}$ & & & \\
$\mathrm{X}_{2}$ & & & \\
$\mathrm{X}_{3}$ & 0,582 & 0,339 & Berpengaruh \\
$\mathrm{X}_{4}$ & & & \\
$\mathrm{X}_{5}$ & & & \\
\hline
\end{tabular}

\section{Uji koefisien regresi secara bersama-sama (uji-F)}

Uji $\mathrm{F}$ digunakan untuk mengetahui pengaruh variabel independen $\left(\mathrm{X}_{1}, \mathrm{X}_{2}, \mathrm{X}_{3}, \mathrm{X}_{4}, \mathrm{X}_{5}\right)$ secara bersamasama terhadap variabel dependen (Y). Hasil uji-F dapat dilihat pada Tabel 3. Berdasarkan hasil uji-F diperoleh nilai F-hitung > F-tabel yaitu 3,402 > 2,477 sehingga hipotesis yang menyatakan bahwa variabel bukti fisik $\left(\mathrm{X}_{1}\right)$,variabel kehandalan $\left(\mathrm{X}_{2}\right)$, variabel daya tanggap $\left(\mathrm{X}_{3}\right)$, variabel jaminan $\left(\mathrm{X}_{4}\right)$ dan variabel empati $\left(\mathrm{X}_{5}\right)$ secara bersama-sama atau secara serentak berpengaruh terhadap variabel tingkat kepuasan pengunjung (Y).

Tabel 3. Hasil Uji-F

\begin{tabular}{cccc}
\hline Variabel & F-hit & F-tabel & Keterangan \\
\hline $\mathrm{X}_{1}$ & & & \\
$\mathrm{X}_{2}$ & 3,688 & & Berpengaruh \\
$\mathrm{X}_{3}$ & & 2,477 & \\
\end{tabular}


$\mathrm{X}_{4}$

$\mathrm{X}_{5}$

\section{Uji regresi secara parsial (uji- $t$ )}

Uji regresi secara parsial (uji- t) digunakan untuk mengetahui model regresi variabel independen $\left(\mathrm{X}_{1}, \mathrm{X}_{2}, \mathrm{X}_{3}, \mathrm{X}_{4}, \mathrm{X}_{5}\right)$ secara parsial (individu) berpengaruh signifikan atau tidak terhadap variabel dependen (Y). Uji-t dapat dilihat pada Tabel 4.

Tabel 4. Hasil Uji-t

\begin{tabular}{ccccc}
\hline Var & t- & & & \\
iab & hitung & t-tabel & & Keterangan \\
el & & Sig & \\
\hline
\end{tabular}

\begin{tabular}{|c|c|c|c|c|}
\hline $\mathrm{X}_{1}$ & 2,989 & 1,688 & 0,005 & Berpengaruh \\
\hline$X_{2}$ & 2,231 & 1,688 & 0,032 & $\begin{array}{c}\text { Berpengaruh } \\
\text { Tidak }\end{array}$ \\
\hline$X_{3}$ & $-0,632$ & 1,688 & 0,532 & $\begin{array}{c}\text { Berpengaruh } \\
\text { Tidak }\end{array}$ \\
\hline $\mathrm{X}_{4}$ & $-2,101$ & 1,688 & 0,043 & $\begin{array}{c}\text { Berpengaruh } \\
\text { Tidak }\end{array}$ \\
\hline$X_{5}$ & $-0,180$ & 1,688 & 0,858 & Berpengaruh \\
\hline
\end{tabular}

Berdasarkan uji-t variabel bukti fisik $\left(\mathrm{X}_{1}\right) \mathrm{t}$-hitung $>$ t-kritis yaitu 2,989 > 1,688 dengan signifikan 0,005 < 0.05 , variabel kehandalan $\left(\mathrm{X}_{2}\right)$ t-hitung $>\mathrm{t}$-kritis yaitu $2,231>1,688$ dengan signifikan $0,056<0.05$ artinya kedua variabel ini memberikan pengaruh yang signifikan terhadap tingkat kepuasan pengunjung (Y). Variabel daya tanggap $\left(\mathrm{X}_{3}\right)$ t-hitung $\leq \mathrm{t}$-kritis yaitu $0,632 \leq 1,688$ dengan signifikan $0,532>0.05$, variabel jaminan $\left(\mathrm{X}_{4}\right) \quad$ t-hitung $\leq \mathrm{t}$-kritis yaitu $-2,101 \leq 1,688$ dengan nilai signifikan $0,048<0.05$ dan variabel empati $\left(\mathrm{X}_{5}\right)$ t-hitung $\leq \mathrm{t}$-kritis yaitu $-0,180 \leq 1,688$ dengan signifikan $0,858>0.05$ artinya ketiga variabel ini tidak memberikan pengaruh yang signifikan terhadap tingkat kepuasan pengunjung $(\mathrm{Y})$.

\section{Analisis Regresi Linear Berganda}

Hasil analisis regresi linear berganda menghasilkan persamaan regresi untuk mengetahui tingkat kepuasan pengunjung $(\mathrm{Y})$ sebagai berikut: $\mathrm{Y}^{\prime}=$ $16,661 \mathrm{a}+0,591 \mathrm{X}_{1}+0,322 \mathrm{X}_{2}-0,205 \mathrm{X}_{3}-0,693 \mathrm{X}_{4}-$ $0,072 \mathrm{X}_{5}$

Berdasarakan persamaan regresi tersebut dapat diartikan bahwa:

1. Sebagai nilai konstanta bernilai positif sebesar 16,661 artinya jika tidak dipengaruhi oleh variabel independen meliputi bukti fisik $\left(\mathrm{X}_{1}\right)$, kehandalan $\left(\mathrm{X}_{2}\right)$, daya tanggap $\left(\mathrm{X}_{3}\right)$, jaminan $\left(\mathrm{X}_{4}\right)$ dan empati $\left(\mathrm{X}_{5}\right)$ maka variabel dependen yaitu kepuasan pengunjung tidak mengalami perubahan atau bernilai tetap.

2. Pengaruh Variabel Bukti Fisik terhadap Kepuasan Pengunjung

Bukti fisik merupakan fasilitas fisik, perlengkapan, pegawai, dan sarana komunikasi
(Tjiptono et.,al, 2008). Bukti fisik adalah mutu jasa yang dipengaruhi oleh benda berwujud. konsumen akan memperhatikan benda berwujud yang memberi layanan sebagai patokan terhadap kualitas jasa yang ditawarkan. Hal ini berarti bahwa pengelola harus memperhatikan dengan baik segala atribut-atribut yang berkenan dengan kualitas keragaan produk karena sangat berpengaruh kepada kepuasan wisatawan (Alma, 2004). Variabel bukti fisik dalam penelitian ini meliputi fasilitas kenyamanan (tempat duduk, peneduh), penampilan kru kapal rapi dan menarik, kebersihan kapal, dan kerapihan kapal.

Nilai koefisien regresi variabel bukti fisik (X1) pada persamaan regresi bernilai positif, artinya jika variabel bukti fisik (X1) ditingkatkan sedangkan variabel lain tetap maka akan meningkatkan nilai variabel kepuasan pengunjung $(\mathrm{Y})$ dengan kata lain jika item-item pada variabel bukti fisik (X1) yang meliputi fasilitas kenyamanan (tempat duduk, peneduh), penampilan kru kapal rapi \& menarik, kebersihan kapal, dan kerapihan kapal ditingkatkan maka nilai kepuasan pengunjung akan meningkat.

Variabel bukti fisik berpengaruh positif terhadap kepuasan pengunjung Pulau Ketawai. Hal ini dapat dilihat dari nilai koefisien regresi variabel bukti fisik sebesar 0,591 menunjukkan bahwa kualitas pelayanan bukti fisik pada transportasi Pulau Ketawai dapat meningkatkan kepuasan pengunjung sebesar 59,1\%. Hasil penelitian ini dapat menjelaskan bahwa kepuasan pengunjung Pulau Ketawai akan meningkat apabila variabel bukti fisik yang meliputi fasilitas kenyamanan seperti tempat duduk dan peneduh dilengkapi dan diperbaiki, fasilitas keamanan (pelampung, GPS, dll) dilengkapi, penampilan kru kapal rapi \& menarik, kebersihan kapal, dan kerapihan kapal terjaga.

Variabel bukti fisik pada transportasi Pulau Ketawai belum menjamin kepuasan pengunjung dalam perjalanan wisata menuju Pulau Ketawai. Fasilitas kenyamanan seperti tempat duduk masih seadanya bahkan belum menjamin keselamatan pengunjung, bahkan sebagian pengunjung dengan bebas duduk dimana saja tanpa mengutamakan keselamatan. Transportasi menuju Pulau Ketawai belum semua memiliki peneduh kapal untuk para pengunjung yang ingin berlindung dari panas/hujan selama perjalanan. Transportasi kapal menuju Pulau Ketawai secara keseluruhan belum memiliki fasilitas keamanan seperti pelampung yang berguna menyelamatkan diri pada saat terjadi perubahan cuaca atau pun kerusakan kapal, dan GPS yang berguna menentukan titik perjalanan dimana penyedia transportasi lebih menggunakan akal (insting) untuk sampai ke Pulau Ketawai. Penampilan kru penyedia transportasi pun menjadi tolak ukur kepuasan pengunjung disaat kru berpenampilan rapi dan menarik serta menjaga kerapihan dan kebersihan kapal. Hal ini akan berdampak pada peningkatan kepuasan pengunjung maka penyedia jasa trasnpostasi Pulau Ketawai harus memperhatikan faktor-faktor variabel bukti fisik untuk menunjang pengembangan pariwisata dalam pencapaian sebuah objek wisata dan menjadi aspek utama dalam perjalanan wisata. 
3. Pengaruh Variabel Kehandalan terhadap Kepuasan Pengunjung

Kehandalan merupakan kemampuan memberikan pelayanan yang dijanjikan dengan segera, akurat dan memuaskan (Tjiptono et.,al, 2008). Kinerja harus sesuai dengan harapan pelanggan yang berarti ketepatan waktu, pelayanan yang sama untuk semua pelanggan tanpa kesalahan, sikap yang simpatik, dan keakuratan yang tinggi (Lupiyoadi dan Hamdani, 2009). Variabel kehandalan dalam penelitian ini meliputi kesesuaian biaya/tarif yang ditawarkan, ketepatan waktu keberangkatan, rasa nyaman dan rasa aman.

Nilai koefisien regresi variabel kehandalan $\left(\mathrm{X}_{2}\right)$ pada persamaan regresi bernilai positif, artinya jika variabel kehandalan $\left(\mathrm{X}_{2}\right)$ ditingkatkan sedangkan variabel lain tetap maka akan meningkatkan nilai variabel kepuasan pengunjung (Y) dengan kata lain jika item-item pada variabel kehandalan $\left(\mathrm{X}_{2}\right)$ yang meliputi kesesuaian biaya/tarif yang ditawarkan, ketepatan waktu keberangkatan, rasa nyaman dan rasa aman ditingkatkan maka nilai kepuasan pengunjung akan meningkat.

Variabel kehandalan berpengaruh positif terhadap kepuasan pengunjung Pulau Ketawai. Hal ini dapat dilihat dari nilai koefisien regresi variabel kehandalan sebesar 0,322 menunjukkan bahwa kualitas pelayanan kehandalan pada transportasi Pulau Ketawai dapat meningkatkan kepuasan pengunjung sebesar 32,2\%. Hasil penelitian ini dapat menjelaskan bahwa kepuasan pengunjung Pulau Ketawai akan meningkat apabila variabel kehandalan seperti biaya/tarif perjalanan disesuaikan dengan penumpang atau dengan kata lain tidak melebihi tarif yang telah ditetapkan. Ketepatan waktu berangkat dapat dijadwalkan dengan baik oleh penyedia jasa transportasi serta memberikan rasa percaya dalam meyakinkan transoprtasi yang digunakan dapat menunjang keamanan dan kenyamanan pengunjung Pulau Ketawai.

Variabel kehandalan pada transportasi Pulau Ketawai menunjukkan bahwa biaya/tarif perjalanan pengunjung Pulau Ketawai tidak disesuaikan dengan jumlah penumpang atau dengan kata lain melebihi tarif yang telah ditetapkan. Ketepatan waktu keberangkatan yang berkaitan dengan pasang surut air laut, cuaca, bahan bakar, dan hal lainnya seperti menunggu jumlah penumpang hingga mencukupi jumlah yang ditargetkan masih belum bisa diprediksikan secara cepat sehingga mengakibatkan pengunjung harus menunggu lama di dermaga/pelabuhan keberangkatan sampai kapal ke Pulau Ketawai siap diberangkatkan. Kondisi pasang surut air laut berperan penting dalam kegiatan wisata. Pasang surut air laut sangat berpengaruh pada keberangkatan transportasi perairan khususnya kapal yang akan menuju Pulau Ketawai. Saat air surut disaat jam keberangkatan yang telah dijanjikan maka pengunjung akan menunggu lama hingga air pasang dan kapal siap diberangkatkan namun tarif yang ditetapkan sama, selain itu wakttu rekreasi akan lebih singkat karena kapal akan kembali ke dermaga sebelum air laut surut kembali. Hal ini akan berdampak pada peningkatan kepuasan pengunjung maka penyedia jasa trasnpostasi Pulau Ketawai harus memperhatikan faktorfaktor kehandalan seperti memastikan waktu yang tepat dalam membuka trip perjalanan wisata berkaitan dengan jadwal pasang surut sehingga pengunjung dapat tahu pasti jadwal keberangkatan serta tidak merasa dirugikan dengan biaya yang sudah dikeluarkan, memberi rasa aman dan nyaman dengan fasilitas yang sesuai standar keselamatan selama perjalanan yang dapat meningkatkan kepuasan pengunjung.

\section{Pengaruh Variabel Daya Tanggap terhadap Kepuasan Pengunjung}

Daya tanggap merupakan keinginan para staf untuk membantu para konsumen dan memberikan pelayanan dengan tanggap (Tjiptono et.,al, 2008). Membantu dan memberikan pelayanan yang cepat dan tepat kepada pelanggan, dengan penyampaian informasi yang jelas (Lupiyoadi dan Hamdani, 2009). Responsivitas menyangkut dengan keinginan dan kesiapan petugas dalam memberikan pelayanan, reaksi dan keinginan dalam membantu dan memberikan pelayanan pada wisatawan dan ketanggapan dalam menyampaikan informasi penting dengan segera (Pitana dan Diarta, 2009). Variabel daya tanggap dalam penelitian ini meliputi ketersediaan pelayanan kapal, pelayanan yang cepat dan tanggap, dan kesiapan kru membantu pengunjung.

Nilai koefisien regresi variabel daya tanggap (X3) pada persamaan regresi bernilai negatif, artinya jika variabel daya tanggap (X3) ditingkatkan sedangkan variabel lain tetap maka akan menurunkan nilai variabel kepuasan pengunjung (Y) dengan kata lain jika itemitem pada variabel daya tanggap (X3) yang meliputi ketersediaan pelayanan kapal, pelayanan yang cepat dan tanggap, dan kesiapan kru membantu pengunjung ditingkatkan maka nilai kepuasan pengunjung akan menurun.

Variabel daya tanggap berpengaruh negatif terhadap kepuasan pengunjung Pulau Ketawai. Hal ini dapat dilihat dari nilai koefisien regresi variabel daya tanggap sebesar -0,205 menunjukkan bahwa kualitas pelayanan variabel daya tanggap pada transportasi Pulau Ketawai dapat menurunkan kepuasan pengunjung sebesar 20,5\%. Hasil penelitian ini dapat menjelaskan bahwa kepuasan pengunjung Pulau Ketawai akan menurun apabila ketersediaan pelayanan kapal tidak tersedia tiap waktu, pelayanan tidak dilakukan dengan cepat dan tanggap oleh penyedia jasa transportasi, dan tidak ada kesiapan kru untuk membantu pengunjung Pulau Ketawai.

Variabel daya tanggap pada transportasi Pulau Ketawai menunjukkan bahwa ketersediaan pelayanan kapal sudah dianggap baik karena kapal tersedia setiap hari baik hari kerja maupun libur. Pelayanan oleh penyedia jasa yang cepat dan tanggap dan kesiapan kru membantu pengunjung sudah dilakukan secara baik oleh penyedia jasa transportasi setiap melayani pengunjung yang ada. Pengunjung tidak kesulitan mencari dan menghubungi dalam ketanggapan para pengantar pengunjung saat akan melakukan perjalanan menuju Pulau Ketawai. Hal ini menunjukkan bahwa penyedia jasa transportasi Pulau Ketawai harus mempertahankan faktor-faktor variabel daya tanggap dalam menyediakan layanan transportasi sehingga tidak menurunkan tingkat kepuasan pengunjung. 
5. Pengaruh Variabel Jaminan terhadap Kepuasan Pengunjung

Jaminan merupakan prilaku para karyawan mampu menumbuhkan kepercayaan pelanggan terhadap perusahaan dan perusahaan bisa menumbuhkan rasa aman bagi para pelangganya, selalu bersikap sopan dan mengusai pengetahuan dan keterampilan yang dibutuhkan untuk menangani setiap pertanyaan atau masalah pelanggan (Tjiptono et.,al, 2008). Jaminan menyangkut dengan pengetahuan, kemampuan, dan keramah tamahan petugas, dan juga berhubungan dengan reputasi pelayanan terhadap wisatawan (Pitana dan Diarta, 2009). Variabel jaminan dalam penelitian ini meliputi kru mengenal tentang Pulau Ketawai, kru bersikap ramah dan sopan, dan kru menjamin keselamatan pengunjung seperti jaminan kesehatan/ kecelakaan.

Nilai koefisien regresi variabel jaminan (X4) pada persamaan regresi bernilai negatif, artinya jika variabel jaminan (X4) ditingkatkan sedangkan variabel lain tetap maka akan menurunkan nilai variabel kepuasan pengunjung $(\mathrm{Y})$ dengan kata lain jika item-item pada variabel jaminan (X4) yang meliputi kru mengenal tentang Pulau Ketawai, kru bersikap ramah dan sopan, dan kru menjamin keselamatan pengunjung ditingkatkan maka nilai kepuasan pengunjung akan menurun.

Variabel jaminan berpengaruh negatif terhadap kepuasan pengunjung Pulau Ketawai. Hal ini dapat dilihat dari nilai koefisien regresi variabel kehandalan sebesar 0,693 menunjukkan bahwa kualitas pelayanan variabel jaminan pada transportasi Pulau Ketawai dapat menurunkan kepuasan pengunjung sebesar $69,3 \%$. Hasil penelitian ini dapat menjelaskan bahwa kepuasan pengunjung Pulau Ketawai akan menurun apabila kru tidak mampu mengenalkan atau menceritakan tentang Pulau Ketawai baik dari daya tarik maupun daya dukung yang ada di Pulau tersebut ataupun sebaliknya kru mengenalkan atau menceritakan tentang Pulau Ketawai secara berlebih sehingga pengunjung tidak dapat mencari tahu sendiri tentang Pulau Ketawai dan merasa terganggu, kru bersikap tidak ramah dan tidak sopan terhadap pengunjung Pulau Ketawai, dan kru tidak menjamin keselamatan pengunjung baik dari rasa aman maupun nyaman selama menempuh perjalanan menuju Pulau Ketawai atau sebaliknya pengunjung menjadi lebih bebas dan sulit dikendalikan oleh kru.

Variabel jaminan pada transportasi Pulau Ketawai menunjukkan bahwa sikap penyedia jasa transportasi Pulau Ketawai sudah dapat menggambarkan dan menceritakan situasi perjalanan dan situasi Pulau Ketawai, kru bersikap ramah dan sopan pada setiap pengunjung yang datang dan disambut dengan baik tanpa membeda-bedakan karakteristik pengunjung, namun kru sejauh ini belum menunjang jaminan dengan memberikan jaminan berupa jaminan kesehatan/kecelakaan secara resmi karena dirasa sejauh ini pengembangan transportasi pariwisata Pulau ketawai dianggap aman dan bisa dikendalikan karena belum/ tidak pernah terjadi permasalahan selama perjalanan. Hal ini menunjukkan bahwa penyedia jasa transportasi Pulau Ketawai harus mempertahankan faktor-faktor variabel jaminan dalam menyediakan layanan transportasi sehingga tidak menurunkan tingkat kepuasan pengunjung.

\section{Pengaruh Variabel Empati terhadap Kepuasan} Pengunjung

Empati merupakan kemudahan dalam melakukan hubungan, komunikasi yang baik, perhatian pribadi, dan memahami kebutuhan para pelanggan (Tjiptono et.,al, 2008). Empati yaitu faktor yang berkaitan dengan perhatian secara pribadi dari petugas kepada wisatawan menyangkut dengan kebutuhan wisatawan, emosi wisatawan, keluhan wisatawan dan sebagainya (Pitana dan Diarta, 2009). Variabel empati meliputi kru menjawab setiap pertanyaan pengunjung tentang trip wisata Pulau Ketawai, kru menerima setiap keluhan pengunjung, dan perlakuan yang sama antar pengunjung.

Nilai koefisien regresi variabel empati (X5) pada persamaan regresi bernilai negatif, artinya jika variabel empati (X5) ditingkatkan sedangkan variabel lain tetap maka akan menurunkan nilai variabel kepuasan pengunjung $(\mathrm{Y})$ dengan kata lain jika item-item pada variabel empati (X5) yang meliputi kru menjawab setiap pertanyaan pengunjung tentang trip wisata Pulau Ketawai, kru menerima setiap keluhan pengunjung, dan perlakuan yang sama antar pengunjung ditingkatkan maka nilai kepuasan pengunjung akan menurun.

Variabel empati berpengaruh negatif terhadap kepuasan pengunjung Pulau Ketawai. Hal ini dapat dilihat dari nilai koefisien regresi variabel kehandalan sebesar -0,072 menunjukkan bahwa kualitas pelayanan variabel daya tanggap pada transportasi Pulau Ketawai dapat menurunkan kepuasan pengunjung sebesar 7,2 \%. Hasil penelitian ini dapat menjelaskan bahwa Kepuasan pengunjung Pulau Ketawai akan menurun apabila kru tidak mampu menjawab setiap pertanyaan pengunjung tentang wisata Pulau Ketawai, kru tidak mampu menerima dan mengatasi setiap keluhan pengunjung, dan tidak memberi perlakuan yang sama antar pengunjung.

Variabel empati pada transportasi Pulau Ketawai menunjukkan bahwa penyedia jasa tranportasi sudah mampu menjawab dan menerima setiap keluhan pengunjung pengunjung yang datang ke Pulau Ketawai. Penyedia jasa tranportasi mampu bersosialisasi dengan baik pada pengunjung Pulau Ketawai serta memberikan perlakuan adil antara pengunjung satu dengan yang lainnya tanpa membeda-bedakan pengunjung yang ada. Hal ini menunjukkan bahwa penyedia jasa transportasi Pulau Ketawai harus mempertahankan faktor-faktor variabel empati dalam menyediakan layanan transportasi sehingga tidak menurunkan tingkat kepuasan pengunjung.

\section{SIMPULAN DAN SARAN}

\section{SIMPULAN}

Penelitian tentang Analisis Kepuasan Pengunjung terhadap Sarana Transportasi Pulau Ketawai Kabupaten Bangka Tengah didapat kesimpulan bahwa bahwa variabel bukti fisik $\left(\mathrm{X}_{1}\right)$ dan variabel kehandalan $\left(\mathrm{X}_{2}\right)$ 
merupakan variabel yang berpengaruh positif terhadap peningkatan kepuasan pengunjung sedangkan variabel daya tanggap $\left(\mathrm{X}_{3}\right)$, variabel jaminan $\left(\mathrm{X}_{4}\right)$ dan variabel empati $\left(\mathrm{X}_{5}\right)$ merupakan variabel yang berpengaruh negatif terhadap peningkatan kepuasan pengunjung.

\section{SARAN}

Saran yang dapat diberikan pada penelitian ini adalah:

1. Perlunya pertimbangan bagi pihak pemerintah ataupun swasta dalam memperbaiki dan memfasilitasi bukti fisik $\left(\mathrm{X}_{1}\right)$ kapal seperti memberikan bantuan fasilitas keamanan seperti pelampung, GPS, dll dan fasilitas kenyamanan seperti tempat duduk dan peneduh dan kehandalan $\left(\mathrm{X}_{2}\right)$ seperti memberikan arahan dan membantu menjadwalkan trip wisata menuju Pulau Ketawai yang tepat sesuai dengan keadaan pasang surut air laut, tarif yang harus dikeluarkan dan jumlah waktu kunjungan yang sesuai karena hal ini berpengaruh terhadap peningkatan kepuasan pengunjung dalam pengembangan sarana transportasi Pulau Ketawai.

2. Masyarakat Desa Kurau yang berprofesi sebagai penyedia jasa transportasi menuju Pulau Ketawai harus memperhatikan kesesuaian bukti fisik $\left(\mathrm{X}_{1}\right)$ dan kehandalan $\left(\mathrm{X}_{2}\right)$ untuk menjamin peningkatan kepuasan pengunjung.

\section{DAFTAR PUSTAKA}

Alma, B. 2004. Manajemen Pemasaran dan Pemasaran Jasa. Alvabeta : Bandung.

Fauzi, A. 2001. An Economic Analysis of The Surplus Production: And Aplication For Indonesian Small Pelagic Fishery. Jurnal Prosiding Presentasi Nasional Seminar Persada. Bogor. 20 Januari 2001.

Ismayanti. 2010. Pengantar Pariwisata. Jakarta : PT Gramedia Widisarana Indonesia.

Kementrian Kelautan Perikanan. 2012. Laporan Akhir Fasilitasi Penyusunan Rencana Zonasi Rinci Kwasan P.Ketawai dan P.bebuar Kabupaten Bangka Tengah Tahun Anggaran 2012. Kabupaten Bangka Tengah Provinsi Kepulauan Bangka Belitung.

Kusmayadi. 2004. Statistika Pariwisata Deskriptif. PT Gramedia Pustaka Utama: Jakarta.

Lupiyoadi, R dan Hamdani, A. 2009. Manajemen Pemasaran Edisi 2. Salemba Empat : Jakarta.

Pitana, I.G dan Diarta, I.K.S. 2009. Pengantar Ilmu Pariwisata. Andi : Yogyakarta.

Priyatno, D. 2013. Analisis Korelasi, Regresi dan Multivariate dengan SPSS. Gava Media :Yogyakarta.

Sugiyono. 2009. Statistika Untuk Penelitian. Bandung : Alfabeta.

Tjiptono, $\mathrm{F}$ dan Chandra, $\mathrm{G}$ dan Andrian, D. 2008. Pemasaran Strategik. Andi : Yogyakarta. 